\title{
SELF-ROTATIONAL DYNAMICS OF DUST GRAINS IN A MAGNETIC FIELD
}

\author{
E.S. DZLIEVA, M.A. ERMOLENKO, M.S. GOLUBEV, A.YU. IVANOV, \\ V.YU. KARASEV
}

PACS 52.90. + z (C) 2011
Institute of Physics, St. Petersburg State University

(1, Ulianovskaya Str., Peterhof, St. Petersburg 198504, Russia)
The self-rotation of dust particles in a magnetic field up to $0.02 \mathrm{~T}$ is researched. The stratified glow discharge and a coaxial magnetic field are used. The dust particles are hollow glass microspheres, whose horizontal deflection is observed. The dependences of the rotation frequency and the direction of dust grains on the magnitude and the direction of a superimposed magnetic field are studied. The hysteresis effect of a particle self-rotation direction at the variation of the magnetic field intensity is examined.

\section{Introduction}

The rotation of a dust grain around its center of inertia (spin) first reported in [1] is of importance for a number of reasons. The grain spin is related to the plasma flux onto the surface of a grain. Since a charged spinning particle possesses a magnetic moment, so there exists the possibility to study the magnetic properties of the dust component. Under certain conditions, the total spin momentum of all dust particles $S$ may exceed the impulse momentum $L$ of the entire dust structure rotating in a magnetic field [2]. Therefore, the consideration of a spin is necessary for a proper understanding of the behavior of complex plasmas in the presence of an external magnetic field. The recently suggested optical method of spin detection using the coordinate tracing and hollow transparent grains [3,4] can essentially supplement our knowledge about the mechanical behavior and the magnetic properties of dusty plasmas.

In the first experiments [3] on a stratified glow discharge, the dependence of the rotation on the magnetic induction was not revealed. The present paper is aimed to investigate the experimental results in more details.

\section{Experiment}

The experimental setup consists of a glow discharge tube, magnetic coil, and visualization system. It has minor changes from the one described in [3].
Glow discharge was generated in a $\mathrm{Ne}-\mathrm{H}_{2}$ mixture in a proportion of $1: 2$ at pressures from 0.3 to 1 Torr. The discharge current was usually $2 \mathrm{~mA}$. The experiment is performed in a stratifed glow discharge, and the plasma parameters are typical, by depending on the pressure and the current: the plasma density is $10^{14}-10^{15} \mathrm{~m}^{3}$; the electron temperature is about $3-4 \mathrm{eV}$; and the longitudinal electric feld is $10-20 \mathrm{~V} / \mathrm{cm}$.

The magnetic field coaxial with the tube was oriented vertically upward. Its magnitude altered usually from 0 to $160 \mathrm{G}$, which is associated with the discharge stability and the presence term of only one dust particle in the stratum.

The visualization system consists of a microscope MBS-9 and a semiconductor laser module and a video camera connected to it. The magnification of the optical system is about $220 \mathrm{X}$. The rotation was measured by the coordinate tracing technique which is described in $[3,4]$ in detail. The system allows the angular frequency registration from 80 to $2000 \mathrm{~Hz}$.

The dust particles we used are hollow transparent glass microspheres injected into the stratum by one. The radii of particles were from 5 to $25 \mu \mathrm{m}$.

\section{Results}

The character of a variation of the own rotation frequency with the magnetic field is individual for every particle. Briefly reporting, we can notice a few major points.

The first result is only a minor deviation of the angular velocity of the rotation of particles (without a magnetic field) at the switching-on of a magnetic field with a strength up to $200 \mathrm{G}$. For majority particles, no change of the angular velocity was observed within errors.

In addition, it has been established that there is an asymmetry of the dependence of the angular velocity of the rotation on the magnetic field strength at its increase and reduction. As the magnetic field increases, the obtained curve lies lower, than that, when the magnetic 


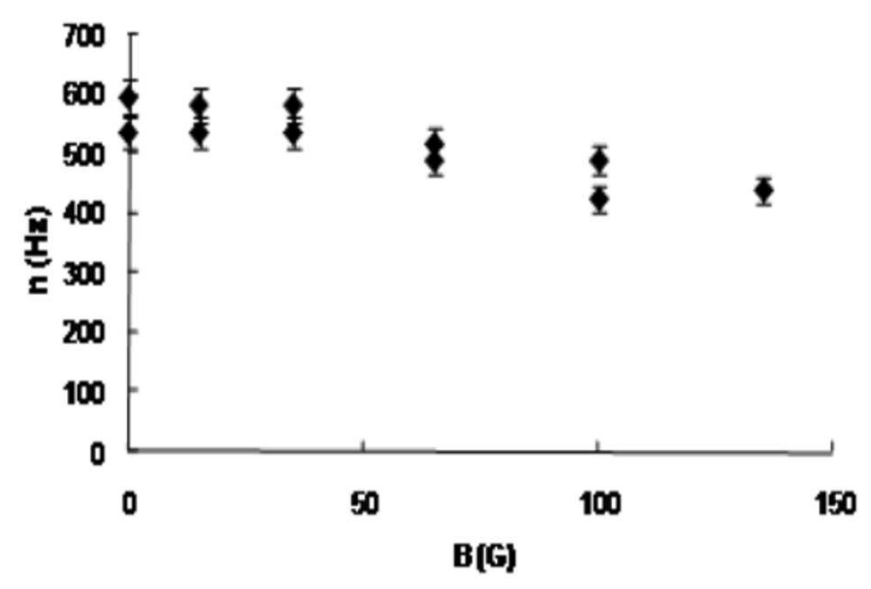

Fig. 1. Dependence of the own rotation frequency of a spherical particle on the magnetic field at its increase (the bottom curve) and reduction (the top curve). The size of a particle is $20 \mu \mathrm{m}$, the current equals $2 \mathrm{~mA}$, the gas is a mixture of neon with hydrogen $(2: 1)$ at a pressure of 0.3 Torr

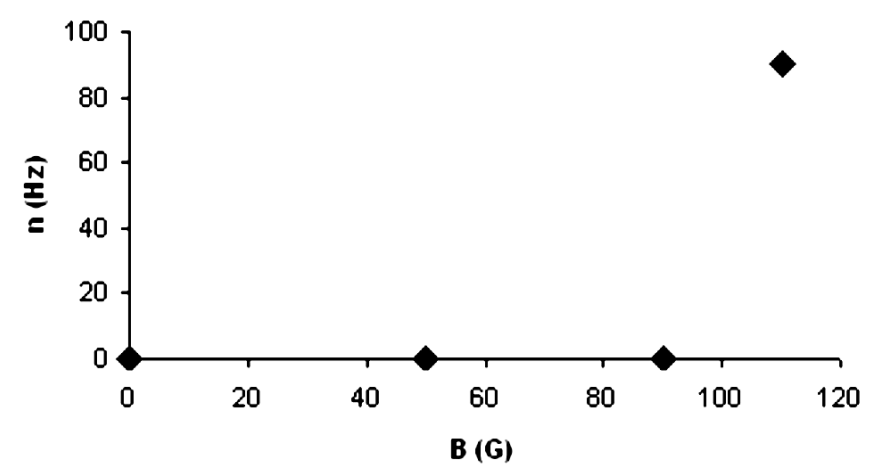

Fig. 2. Threshold of the rotation of a spherical particle in a magnetic field. The size of a particle is $10 \mu \mathrm{m}$, the current equals 2.5 $\mathrm{mA}$, the gas is $\mathrm{Ne}$ at a pressure of 0.4 Torr

field decreases under the same conditions (see Fig. 1). We call the given effect as the hysteresis of the angular velocity of a dust top in a magnetic field.

The imposed magnetic field has shown the threshold character of rotation for the particles which reveal no rotation without a magnetic field. Figure 2 shows the effect for a typical particle-sphere with the absence of essential defects of a surface, which was determined by speckles at the illumination of a particle by the laser.

When a magnetic field is absent, the rotation direction of particles is random. Under the action of a magnetic field, the angular velocity of particles is aligned against the direction of the magnetic induction.

\section{Conclusion}

The observations of single dust granules with high optical magnification and the application of the coordinate tracing technique have allowed us to register the threshold effect of rotation of dust granules in a magnetic field. These observations at the kinetic level explain a change of the number of rotating dust particles found out in [1] and show that the dusty plasma has the paramagnetic properties.

The obtained results indicate the presence of two independent mechanisms inducing the dust particle rotation: one is caused by the action of a magnetic field on the existing magnetic dipole, and another one is caused by plasma flows. But the threshold character of rotation and the effect of its hysteresis in a magnetic field up to $200 \mathrm{G}$ demand the further researches of the rotation in a greater range of changes of a magnetic field [5-10].

The work was supported by the RFBR Grant No. 0808-00628.

1. K. Fukagawa, G. Uchida, S. Iizuka, and N. Sato, in Proceedings of the Conference ICPIG-XXV (Nagoya University, Nagoya, 2001), Vol. 3, p.37.

2. E.S. Dzlieva, V.Yu. Karasev, and A.I. Eikhvald, in Proceedings of the Conference on Physics of Low Temperature Plasma (PetrGU, Petrozavodsk, 2004), Vol. 1, p. 265 (in Russian).

3. V.Yu. Karasev, E.S. Dzlieva, A.I. Eichvald et al., Phys. Rev. E 79, 026406 (2009).

4. E.S. Dzlieva, M.S. Golubev, V.Yu. Karasev, in Proceedings of Intern. Conf. PNP-13, Chernogolovka, 2009, p. 70 .

5. V.Yu. Karasev, E.S. Dzlieva, M.A. Ermolenko, M.S. Golubev, and A.Yu. Ivanov, Contr. Plasma Phys. 51, 509 (2011).

6. E.S. Dzlieva, V.Yu. Karasev, M.A. Ermolenko, and S.I. Pavlov, Vestnik SPbGU, No. 3, 104 (2011).

7. V.Yu. Karasev., Vestnik SPbGU Is. 3.107 (2011).

8. E.S. Dzlieva and V.Yu. Karasev., in Proc. Conference on Physics of Low Temperature Plasma (PetrGU, Petrozavodsk, 2011), Vol. 2, p. 201 (in Russian).

9. M.M. Macar, S.I. Pavlov, E.S. Dzlieva, V.Yu. Karasev, and N.S. Afanaseva, in Proc. Conference ONFI-2011 (Moscow, 2011).

10. E.S. Dzlieva, V.Yu. Karasev, and O.F. Petrov, JETP 141, No. 1 (2012).

Received 19.01.11 
ДИНАМІКА ВЛАСНОГО ОБЕРТАННЯ ПИЛОВИХ

ЧАСТИНОК У МАГНІТНОМУ ПОЛІ

О.С. Дзлієва, М.А. Єрмоленко, М.С. Голубев, А.Ю. Іванов, В.Ю. Карасъов

$\mathrm{P}$ е $з$ ю м е

У статті досліджено обертаючий рух пилових частинок навколо центра інерції у магнітному полі з індукцією до 200 Гс.
Експеримент виконано у стратифікованому розряді у поздовжньому магнітному полі. У ролі пилових частинок використано порожнисті скляні мікросфери. Методом регістрації обертання виступає метод розгортки розсіяного світла в горизонтальному напрямку. Вивчено залежності величини i напрямку кутової швидкості частинок від величини i полярності магнітного поля. Показано, що власне обертання частинок у магнітному полі має властивість гістерезису. 